OPEN ACCESS

Edited by:

Mauricio Antonio Retamal, Universidad del Desarrollo, Chile

Reviewed by:

Holger Jahr,

University Hospital RWTH Aachen,

Germany

Yoshiaki Suzuki,

Nagoya City University, Japan

Tsutomu Maeda,

Shiga University of Medical Science,

Japan

*Correspondence:

Richard Barrett-Jolley rbj@liv.ac.uk

Specialty section:

This article was submitted to Membrane Physiology and Membrane

Biophysics,

a section of the journal

Frontiers in Physiology

Received: 26 August 2015 Accepted: 11 November 2015 Published: 01 December 2015

Citation:

Lewis R and Barrett-Jolley R (2015) Changes in Membrane Receptors and Ion Channels as Potential Biomarkers

for Osteoarthritis.

Front. Physiol. 6:357.

doi: 10.3389/fphys.2015.00357

\section{Changes in Membrane Receptors and Ion Channels as Potential Biomarkers for Osteoarthritis}

\author{
Rebecca Lewis ${ }^{1}$ and Richard Barrett-Jolley ${ }^{2 *}$ \\ ${ }^{1}$ Faculty of Health and Medical Sciences, School of Veterinary Medicine and Science, University of Surrey, Guildford, UK, \\ ${ }^{2}$ Department of Musculoskeletal Biology, Faculty of Health and Life Sciences, Institute of Ageing and Chronic Disease, \\ University of Liverpool, Liverpool, UK
}

Osteoarthritis $(\mathrm{OA})$, a degenerative joint condition, is currently difficult to detect early enough for any of the current treatment options to be completely successful. Early diagnosis of this disease could increase the numbers of patients who are able to slow its progression. There are now several diseases where membrane protein biomarkers are used for early diagnosis. The numbers of proteins in the membrane is vast and so it is a rich source of potential biomarkers for OA but we need more knowledge of these before they can be considered practical biomarkers. How are they best measured and are they selective to OA or even certain types of OA? The first step in this process is to identify membrane proteins that change in OA. Here, we summarize several ion channels and receptors that change in OA models and/or OA patients, and may thus be considered candidates as novel membrane biomarkers of OA.

Keywords: ion channels, osteoarthritis, biomarkers, chondrocytes, cartilage

\section{INTRODUCTION}

Early diagnosis of osteoarthritis $(\mathrm{OA})$ is difficult as significant joint damage generally occurs before patients present with pain. MRI screening of risk groups for markers of joint degeneration, by definition, requires that some degeneration has already taken place. Although, there is a clear correlation between the presence of cartilage-denuded zones of subchondral bone in knee joints and pain severity (Cotofana et al., 2013), the overall correlation between physical indicators of joint degeneration and osteoarthritic pain is statistically significant, but weak (Hunter et al., 2013; Eckstein et al., 2015) therefore alternative markers of early OA are urgently needed. Membrane proteins are a potential source of novel biomarkers. A normal human cellular membrane contains thousands of proteins, so this review will focus largely on ion channels and membrane proteins involved with intercellular signaling. Here we mainly consider the cartilage-producing cells; chondrocytes. There are many other cell types that are also likely to be important for development of OA, such as those of bone, blood vessels, synovial tissue or nerves, but these are beyond the scope of this review.

\section{MEMBRANE PROTEINS AS BIOMARKERS OF OSTEOARTHRITIS}

The term "biomarker" is often misappropriated to mean just soluble biomarkers useable for diagnostics, but in fact the WHO organization defines the term much more broadly "almost any measurement reflecting an interaction between a biological system and a potential hazard, 
which may be chemical, physical, or biological. The measured response may be functional and physiological, biochemical at the cellular level, or a molecular interaction." (Strimbu and Tavel, 2010). Plasma membrane proteins could therefore constitute useful biomarkers in a number of contexts. Firstly, recent developments of adaptamer and nanotechnologies (Gao et al., 2004; Hwang et al., 2010) have demonstrated that changes in cellular membrane protein components or even those of intracellular compartments can be detected in vivo. Whilst this approach would be more challenging in the hypocellular and avascular environment of cartilage, it may prove possible especially in synovial tissue. As imaging technology becomes more widely available, we need to have potential biomarkers available for it to exploit. Secondly, there are a number of conditions in which membrane proteins, or parts of membrane proteins, are shed and become detectable as soluble biomarkers. For example, in liver cirrhosis, the aquaporin channel (AQP2) is increased both in expression and in urinary excretion (Asahina et al., 1995; Ivarsen et al., 2003; Pedersen et al., 2003). During progression of $\mathrm{OA}$, fragments of the membrane protein syndecans can be detected in synovial fluid (Pap and Bertrand, 2013). A third context in which an expanded knowledge of membrane receptors will prove useful is in genetic screening. It is unlikely that any ion channel or receptor will be found that is unique to components of the joints; if a change in a membrane receptor or channel is detected which is involved with $\mathrm{OA}$ and arises from, for example, a genetic polymorphism, it is logical that this could then be detected with a blood test. Indeed the $\mathrm{Na}_{V} 1.7$ ion channel has already been identified as a potential biomarker of OA in genetic association studies (Thakur et al., 2013). Whilst OA is a complex multi-organ condition, many studies use so called in vitro models of $\mathrm{OA}$ however these are largely unvalidated (Johnson et al., in press); a further, potentially valuable use of membrane biomarkers will be to more precisely characterize these models and compare their differential membrane phenotype with that of tissue from native OA cartilage.

\section{DIFFERENTIALLY EXPRESSED CHANNELS AND RECEPTORS IN OSTEOARTHRITIC CARTILAGE}

The vast majority of studies investigating changes in membrane receptors and ion channels in OA have focussed on chondrocytes, the resident cells of cartilage that detect activity of the joints and respond with production and maintenance of further cartilage (Urban, 1994). Sudden impact loading of joints can damage chondrocytes and will decrease cartilage production (Quinn et al., 2001; Milentijevic et al., 2003; Bush et al., 2005; Natoli et al., 2008), but paradoxically, joint inactivity also leads to reductions in cartilage production (Brandt, 2003). Thus, there appears to be an optimal chondrocyte-loading regime. The frequency of loading and amount of loading are unknown. Evidence suggests that this is disturbed in OA (Millward-Sadler et al., 2000; Vincent, 2013) and so elements of the mechanotransduction system are potentially key sources of novel membrane biomarkers.
Chondrocyte mechanotransduction is poorly understood, but the membrane proteins; integrins, connexins, TRP, piezo, ENaC, and potassium channels have been strongly implicated (MillwardSadler et al., 2000; Mobasheri et al., 2002; Garcia and Knight, 2010; Guilak, 2011; Lewis et al., 2011b, 2013a; O’Conor et al., 2013; Lee et al., 2014) in addition to the soluble mediator, FGF2 (Vincent et al., 2007).

\section{Ion Channels}

In a recent report, we discussed the differential expression of ion channels in OA (Lewis et al., 2013b). We analyzed transcript levels in the (Karlsson et al., 2010) dataset; the acid sensing potassium channel (TASK-2), epithelial sodium channel $(\mathrm{ENaC})$ and $\mathrm{Ca}^{2+}$ activated chloride channel were all decreased (anoctamin-1, TMEM16), whereas $\mathrm{Ca}^{2+}$ activated potassium channels (KCa3.1, "SK" and KCa1.1, "BK") and aquaporin 1 (AQP1) were strongly up-regulated. The tight clustering of differentially expressed channels to ontological functions of mechanotransduction, cell volume regulation and apoptosis suggests that these changes could be linked to progression of OA. To further investigate this channel data we analyzed protein expression of BK in osteoarthritic cartilage by immunohistochemistry and aquaporin expression using a functional (permeability) assay. Both aquaporin and BK were significantly increased in expression in chondrocytes from osteoarthritic cartilage (Lewis et al., 2013a,b). Increased aquaporin channel expression in $\mathrm{OA}$ has also been reported elsewhere (Geyer et al., 2009; Hagiwara et al., 2013; Musumeci et al., 2013) and the AQP1 gene harbors hypomethylated regions of DNA in OA patients indicative of over-expression (Rushton et al., 2014). This striking observation raises the possibility of there being changes in other detectable partners in the volumeregulatory pathway, such as water content, potassium or any of several other cellular markers (Hoffmann et al., 2009). Changes in synovial fluid osmolarity during progression of osteoarthritis could also influence progression of the disease due to the effects on ion channel expression. The ClC7 chloride channel, for example, is downregulated by hypo-osmotic stress, altering membrane potential and leading to increased cell death (Kurita et al., 2015). Another potassium channel, not identified as differentially expressed in our transcriptomic analysis, but linked to OA by more traditional methods, is the ATP sensitive $\mathrm{K}^{+}$ ion channel $\left(\mathrm{K}_{\mathrm{ATP}}\right)$. $\mathrm{K}_{\mathrm{ATP}}$ is a widely expressed ion channel, existing in several isoforms and involved in many human diseases. In our own work we identified $\mathrm{K}_{\mathrm{ATP}}$ channels in chondrocytes (Mobasheri et al., 2007) and a further recent report showed this channel is linked to control of chondrocyte metabolism in a scheme involving the glucose transporter family GLUT-1 and GLUT-3 (Rufino et al., 2013). This function of $\mathrm{K}_{\mathrm{ATP}}$ channels is changed in $\mathrm{OA}$ and implicates changes in chondrocyte metabolism in the complex process of cartilage degeneration.

TRP cation channels are a widely distributed family of channels in the musculoskeletal system that frequently detect changes in the cellular microenvironment and transduce these to electrochemical signals (Guilak et al., 2010). In our own studies we reported that TRPV5 channels were present in healthy 
chondrocytes and facilitated the volume defense mechanism of chondrocytes (Lewis et al., 2011a; Hdud et al., 2012). Interestingly, another TRP ion channel, TRPV4, changes in expression in a mouse model of OA (Lamandé et al., 2011) and knockout of TRPV4 ion channels in mice results in osteoarthritic changes in cartilage (Clark et al., 2010). This channel is therefore a potential biomarker for OA. Indeed, the closely related TRPV1 was also associated to OA pain in the genetic study mentioned above (Thakur et al., 2013). It remains to be seen whether modulation of TRP channel expression or function could be the basis of a plausible therapeutic approach for OA.

A further ion channel reportedly changed in activity in $\mathrm{OA}$ is the N-methyl-D-aspartic acid (NMDA)-receptor. This ion channel is better known as the most abundant excitatory neurotransmitter receptor in the brain. It is activated by glutamate and its presence in chondrocytes is indicative of the complex signaling between chondrocytes and the extracellular matrix (ECM). Several NMDA isoforms have been identified in chondrocytes; NR1, NR2A, NR2B, NR2D, and NR3 (Ramage et al., 2008; Lee et al., 2009; Piepoli et al., 2009) and stimulation of this channel has a number of biological effects, elevation of intracellular $\mathrm{Ca}^{2+}$, activation of $\mathrm{nNOS}$, uncoupling of PDZ, depolarization and cell proliferation (Ramage et al., 2008; Piepoli et al., 2009). The depolarization can be reversed by application of the classical voltage-gated sodium channel blocker (tetrodotoxin). Following such treatment NMDAreceptor activation results in a partially apamin sensitive (i.e., SK mediated) hyperpolarization. The expression pattern of NMDA$\mathrm{R}$ isoforms changes with onset of OA: RT-PCR studies show that chondrocytes from normal cartilage express mRNA for NR1 and NR2A. In the lysate samples tested by Ramage et al. OA chondrocytes showed decreased expression of NR2A, but increased expression of NR2B during onset of OA. Normal chondrocytes show very little proliferative potential, and it is interesting that IL1 $\beta$ activates gene expression in an NMDA$\mathrm{R}$ manner. Therefore, NMDA-R may be involved in cartilage degradation in OA. In terms of soluble biomarkers, changes in membrane receptor expression could be predictive of changes in soluble partner ligand. It is therefore notable that changes in NMDA-R ligands (excitatory amino acids) are indeed altered in OA cartilage (dialysates) (Jean et al., 2005, 2006, 2007).

\section{Histamine Receptors}

Other membrane receptors are also differentially expressed in OA. These include histamine, bradykinin, and prostaglandin receptors, all linked to inflammation and extravasation in tissues. Histamine was probably the earliest pharmacological mediator to be discovered that is strongly linked to inflammation. Typically histamine is released at site of tissue injury and serves to initiate a local inflammatory response. Histamine antagonists are one of the most widely used off the shelf medicines; $\mathrm{H}_{1}$ antagonists have sedative value if they cross the blood brain barrier, but are useful anti-allergenics for hayfever etc., whereas $\mathrm{H}_{2}$ are inhibitors of gastric acid secretion and used in many widely available anti-ulcer medicines. The earliest discovery of histamine receptors in cartilage was indeed of $\mathrm{H}_{1}$ and $\mathrm{H}_{2}$ (Tetlow and Woolley, 2005). Expression of both, together with the histamine producing enzyme histidine decarboxylase was seen to be increased in expression, especially in the superficial zone of OA cartilage (Tetlow and Woolley, 2005). Physiologically, histamine increases intracellular calcium ion concentrations evoked by the ORAI/STIM1 pathway and so hyperpolarizes chondrocytes via BK channels (Funabashi et al., 2010; Inayama et al., 2015). Other studies of histamine receptors in cartilage have focussed on the less well-known $\mathrm{H}_{4}$ histamine receptor: Comparisons between rheumatoid and OA tissue show OA to have greater expression of this receptor (Yamaura et al., 2012b). This could be a key differential marker between the systemic inflammation seen in rheumatoid arthritis and the local inflammation of OA. A further explanation, which goes someway to explain this observation, is that histamine $\mathrm{H}_{4}-\mathrm{R}$ density is elevated in a teratoma-derived pre-chondrocyte cell line, ATDC5, (Yamaura et al., 2012a) providing more evidence of the apparent changes in chondrocyte phenotype as cartilage degenerates, even without inflammation.

\section{Prostaglandin Receptors}

In many ways, bradykinin and the prostaglandins are partners to histamine. They are both central to the early response to tissue injury and inflammation, and released in the tissues along with histamine. Prostaglandins are a family of lipid mediators derived from the cell membrane via the action of phospholipase A2 $\left(\mathrm{PLA}_{2}\right)$ and cyclooxygenase (principally COX-1 and COX2) enzymes. Inhibitors of these enzymes therefore profoundly change the prostaglandin balance in the joint. $\mathrm{PLA}_{2}$ is inhibited by steroid anti-inflammatory drugs and COX-1 and COX-2 are inhibited by typical NSAIDs. The prostaglandin membrane interactions documented to date surround prostaglandin $\mathrm{E}_{2}$ $\left(\mathrm{PGE}_{2}\right)$ and its receptors $\mathrm{EP}_{2}$ and $\mathrm{EP}_{4}$ (Attur et al., 2008; Otsuka et al., 2009). This work has centered on a pharmacological, rather than molecular or immunohistochemical approach. $\mathrm{PGE}_{2}$ is an enzyme typically associated with pro-inflammatory actions (Martel-Pelletier et al., 2003), it binds preferentially to 4 receptors termed $\mathrm{EP}_{1-4}$ and there are a number of relatively selective agonists and antagonists available to distinguish between them (Alexander et al., 2011). PGE 2 membrane receptors have been reported to have diverse actions on OA cartilage, for, whilst the $\mathrm{EP}_{4}$ receptor stimulates activity of a number of catabolic enzymes in OA cartilage (Attur et al., 2008), there are conflicting reports of the actions of $\mathrm{EP}_{2}$-receptor activation. Activation of $\mathrm{PGE}_{2} \mathrm{EP}_{2}$ receptors was reported to decrease proteoglycan secretion in $3 \mathrm{D}$ cultures of human articular chondrocytes ( $\mathrm{Li}$ et al., 2009), but be protective (Mitsui et al., 2011) and to even enhance regeneration of articular cartilage in rabbit OA models (Otsuka et al., 2009). The mechanism of action of each of the $\mathrm{PGE}_{2}$ chondrocyte membrane receptors has not been well studied, however, a role in intracellular $\mathrm{Ca}^{2+}$ handling has been proposed (Xu et al., 2009). Chondrocyte activity is controlled by a complex mechanotransduction mechanism, beginning with the deformation of the cellular membrane and ending with changes in biosynthetic activity. This pathway involves opening of ion channels, change of membrane potential and elevation of intracellular $\mathrm{Ca}^{2+}$. Xu et al. (2009) mimicked this biological activity with direct electrical stimulation of cartilage and found 
the ECM synthesis output was dependent on COX activity (i.e., indomethacin sensitive). Whilst it was inferred that $\mathrm{PGE}_{2}$ receptors were involved this was not tested for with a specific EP-receptor antagonist. Again such involvement of membrane receptors such as the $\mathrm{EP}_{2}$ and $\mathrm{EP}_{4}$ in pathogenesis of $\mathrm{OA}$ presents not just the receptor itself as a potential biomarker (and treatment target), but suggests changes in the associated ligand $\left(\mathrm{PGE}_{2}\right)$ may also be detectable. Indeed this proves to be the case, since $\mathrm{COX}-2$ and $\mathrm{PGE}_{2}$ are both found to be increased in cartilage from OA donors (Amin et al., 1997).

\section{Bradykinin (Kinin) Receptors}

Bradykinin involvement with OA progression was first postulated by the group of Maggi (Meini and Maggi, 2008). Bradykinin contributes to the hyperexcitability of sensory nerves associated with inflammation and also activates the synoviocytes and chondrocytes critical for the homeostasis of synovial fluid and cartilage, respectively. Two bradykinin GPCRs have been identified; $B_{1}$ and $B_{2}$ and both signal through $G_{q / 11}$. Typically bradykinin itself acts on $\mathrm{B} 2$ receptors. A polymorphism in the gene encoding this receptor is associated with OA, and could potentially be a biomarker for OA (Chen et al., 2012). Receptor antagonists toward $\mathrm{B} 2$ receptors have been proposed to be potential treatments for OA (Meini et al., 2011) since they can be protective to cartilage in in vitro models. A role of B2 membrane receptors in pathogensis implies a likely change in bradykinin levels too. This was observed many years ago, however, the change is seen in rheumatoid arthritis too and is not limited to OA (Melmon et al., 1967; Eisen, 1970). The contribution of B2-receptors to the pain and hyperalgesia of osteoarthritis is likely to be mediated by the same mechanisms of other chronic pain conditions, namely the sensitization of primary afferent neurons (Cesare and McNaughton, 1996; Huang et al., 2006), for example by increasing the neuronal expression of TRPV1 like channels via a protein kinase $\mathrm{C}$ ( $\mathrm{PKC})$ dependent pathway. The mechanisms by which $\mathrm{B} 2-\mathrm{R}$ facilitates cartilage breakdown are less well known, however, stimulation of prostaglandin synthesis and activation of EP2 receptors seems likely (Averbeck et al., 2004).

\section{Purinergic Receptors}

There are four members of the purinergic "P1" subfamily; $\mathrm{A}_{1}$ and $A_{3}$ are $G_{i / o}$ coupled receptors, but $A_{2 A}$ and $A_{2 B}$ are coupled to $\mathrm{G}_{s}$. The P2 family are activated by extracellular ATP or ADP and further classified into 2 subfamilies P2X and P2Y. P2X are ligandgated ion channel receptors $\left(\mathrm{P} 2 \mathrm{X}_{1-7}\right)$ with $\mathrm{P} 2 \mathrm{X}_{7}$ being genetically linked to OA pain (Thakur et al., 2013). P2Y are G-protein coupled receptors. There are 14 known members of the P2Y class of membrane receptor and they couple to a variety of different G-proteins, including both $\mathrm{G}_{s}$ and $\mathrm{G}_{\mathrm{i}}$. Several members of this

Key Membrane Receptors and Channels Differentially

Transcribed, Expressed or Implicated in OA

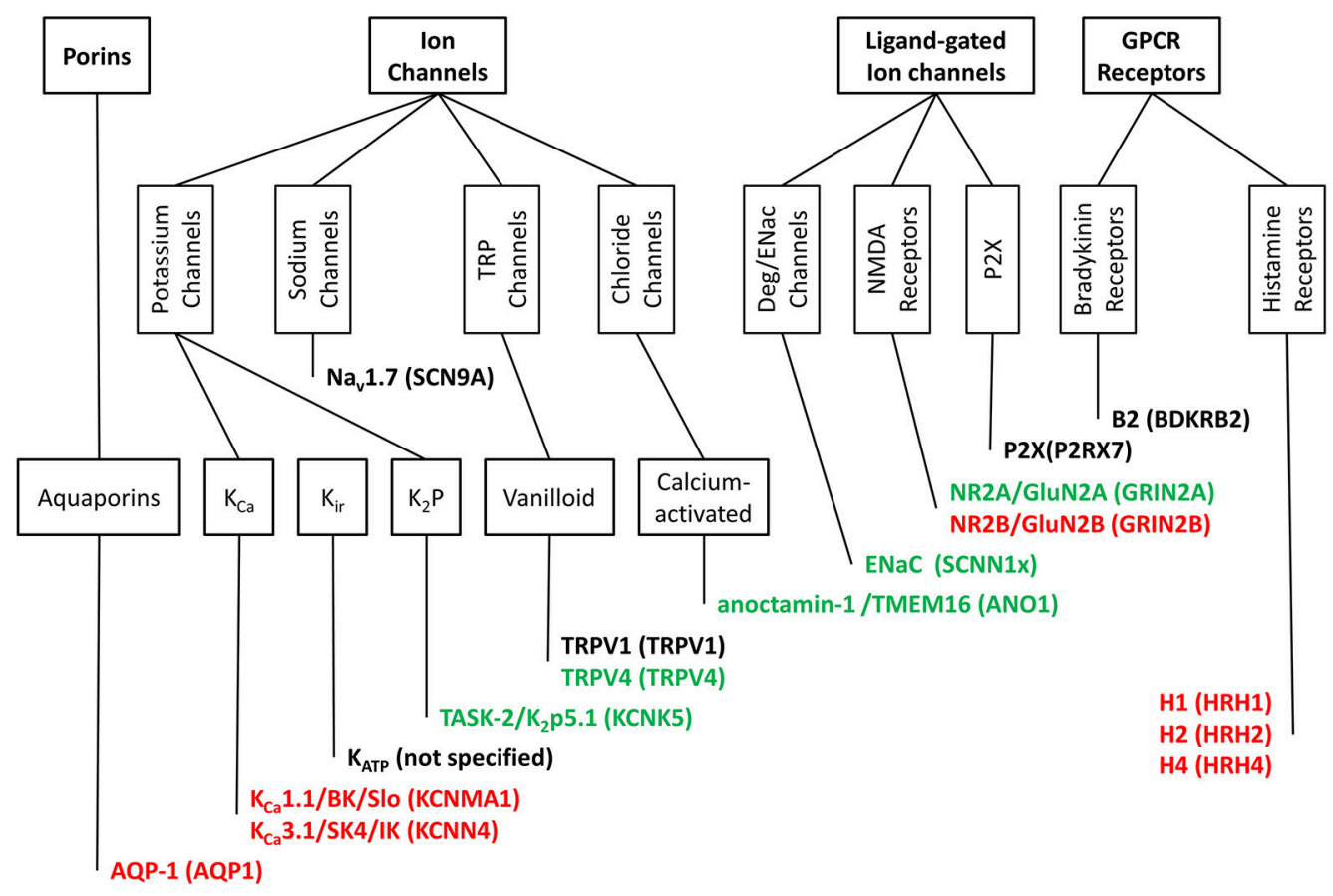

FIGURE 1 | Key membrane receptors and channels differentially transcribed. Expressed or implicated in OA. This figure shows those ion channels and membrane receptors most clearly linked to OA and discussed in the text, classified in accordance with the IUPHAR Guide to Pharmacology database (Pawson et al., 2014). Genes/proteins in red are up regulated in OA, and those in green are down regulated. Those remaining in black are linked to OA, but not specifically increased or decreased (a polymorphism for example). Genes/proteins are given in the following format; common names/alternative names (human gene or equivalent). 
superfamily have been identified in chondrocytes, including; P1 receptor $\mathrm{A}_{2 \mathrm{~A}}$ and $\mathrm{P} 2$ receptors $\mathrm{P}_{2} \mathrm{X}_{2}, \mathrm{P} 2 \mathrm{X}_{3} \mathrm{P} 2 \mathrm{X}_{4}, \mathrm{P} 2 \mathrm{X}_{7}$, and $\mathrm{P}_{2} \mathrm{Y}_{1}$ and $\mathrm{P} 2 \mathrm{Y}_{2}$ (Varani et al., 2008; Knight et al., 2009; Campo et al., 2012b). Most of these receptors are identified throughout cartilage with the notable exception of $\mathrm{P}_{2} \mathrm{Y}_{2}$ which was located to the superficial layers (Knight et al., 2009). Knight found there to be no obvious difference in transcription, but observes that since ATP/P2 receptor signaling is altered in OA elevated levels of ATP could be inducing desensitization of purinergic membrane receptors. In terms of function, there are clear indicators that the
P2 receptor is involved with mechanotransduction coupling, in complex cascades including connexins and integrins (MillwardSadler et al., 2004; Pingguan-Murphy et al., 2006; Knight et al., 2009), whereas an anti-inflammatory role has been proposed for the P1 (adenosine) receptors (Campo et al., 2012a). An important study by Rosenthal et al. (2010) indicates that P1 and P2 purinergic receptors interact to modulate the extracellular inorganic pyrophosphate balance and it seems likely that this too will be in response to mechanical activity, but this has not yet been shown.

TABLE 1 | Other membrane receptors associated or implicated with osteoarthritis, but with less well characterized roles in joint function.

\begin{tabular}{lll}
\hline Receptor & Long name or descriptor & Context \\
\hline LRP-1 & $\begin{array}{l}\text { Low-density lipoprotein receptor-related protein (aka } \\
\text { apolipoprotein E receptor, CD91), reviewed by May et al. }\end{array}$ & $\begin{array}{l}\text { Drives rapid endocytosis of ADAMTS-5; LRP-1 is down-regulated in human articular } \\
\text { (2007) }\end{array}$ \\
\hline
\end{tabular}

InsR/IGF-R Insulin Receptors and Insulin like Growth factor receptors

Both InsR/ILGF-R are decreased in chondrocytes from patients with OA (Rosa et al., 2011) and the IGF-I peptide itself increases expression of COL2A1 in articular chondrocytes (Renard et al., 2012) family), with many ligands such as heat shock proteins and hyaluronic acid oligomers. Includes TLR $1-11$ (Akira and Takeda, 2004)
TLR Toll-like receptor proteins (members of the interleukin receptor

Are more commonly found on inflammatory cells and serve to initiate inflammatory responses/innate immunity. TLR $1-9$ identified in cartilage and are differentially expressed in OA cartilage (Kuroki et al., 2010; Barreto et al., 2013; Yang et al., 2013). Polymorphism of the TLR 3 and TLRg promoted associate with severe OA (Su et al., 2012; Yang et al., 2013) and "alarmins" accelerate catabolism in OA cartilage in a TLR4 dependent mechanism (Schelbergen et al., 2012)

TGF $\beta$-RII expression decreases with age and potentially predisposes older people to OA (Bauge et al., 2013) and its genetic deletion increases OA in mice (Zhen et al., 2013)

PPAR $\gamma$-R is down-regulated in both human OA (Afif et al., 2007) and in several OA models (Fahmi et al., 2011) including the spontaneous Guinea-pig model (Nebbaki et al., 2013). In some cases this is secondary to Erg-1 mediated IL-1 (Nebbaki et al., 2012) and/or TLR 4 activation (Chen et al., 2013)

MC-R Melanocortin peptide receptors, for example $\mathrm{MC}_{1}-\mathrm{R}$ and $\mathrm{MC}_{2}-\mathrm{R}$. Endogenous pharmacological activators include $\alpha$-melanocyte-stimulating hormone $(\alpha-\mathrm{MSH})$, pro-opiomelanocortin (POMC) and adrenocorticotrophin $(\mathrm{ACTH})$

MC1, MC2, MC5, and ligand POMC transcribed in cartilage, induces expression of several ECM components and pro-inflammatory cytokines (Grässel et al., 2009), but can also mediate chondro- and cartilage- protective effects of neuropeptides such as $\alpha-\mathrm{MSH}, \mathrm{POMC}$ in both in vitro and rat in vivo models of OA (Shen et al., 2011; Kaneva et al., 2012)

CD36 A pattern recognizing receptor (Silverstein and Febbraio, 2009). Aka "thrombospondin receptor"

CD36 is well known to increase in OA (Pfander et al., 2000), however, recent data show it is also able to suppress catabolic activity and serves as a marker of hypertrophy (Cecil et al., 2009)

PTH1-R Parathyroid receptor-1 PTH1-R expression is decreased in rabbits with ACL section induced OA (Becher et al., 2010)

Ob-R Leptin receptor

With onset of OA there is a switch from adipokine synthesis to receptor synthesis (Francin et al., 2011). Leptin itself enhances production of catabolic MMP enzymes in OA cartilage (lliopoulos et al., 2007; Koskinen et al., 2011). It is believed that leptin may mediate the pro-OA effects of obesity rather than simply the increased load observed in weight baring joints

CD44 Hyaluronan receptor (aka HA-R)

FGF-R Fibroblast growth factor (FGF) receptors, family includes FGFR1, 2, 3, and 4. Sensitive to the 22 member FGF family
Activation inhibits expression of ADAMTS4 (aggrakinase-1) and MMP-13 in [osteoarthritic] chondrocytes (Yatabe et al., 2009; Julovi et al., 2011), although some hyaluronan effects could be mediated through the TLRs (see below)
FGFR-3 in has been shown to mediate chondroprotective of FGF18 (Ellman et al., 2013). Please see Vincent (2012) for discussion of the role of FGF in OA. 


\section{Estrogen Receptors}

There are two fundamentally different types of estrogen membrane receptor; one is a seven transmembrane (7TM) Gprotein coupled "GPE" receptor. The GPE-receptor couples to both Gs and Gi/o and is thought to mediate rapid, so called nongenomic actions of estrogen. These may be localized in either plasma or intracellular membranes. The second are the steroid intracellular receptors known as $\mathrm{ER} \alpha$ and $\mathrm{ER} \beta$. Both ERs have been identified in joint tissue including chondrocytes (Ushiyama et al., 1999; Martin-Millán and Castañeda, 2013). There have been conflicting reports of association between estrogen receptor gene polymorphisms and human OA. Association between ER $\alpha$ and ER $\beta$ was detected in a study of knee and hip OA (Riancho et al., 2010), whereas polymorphisms of $\operatorname{ER} \beta$ were reported to be only marginally associated with $\mathrm{OA}$ in a study of hand and hip OA (Kerkhof et al., 2010). A large transgenic study showed that mice with double knock-out of both $\operatorname{ER} \alpha$ and $\operatorname{ER} \beta$ were strongly predisposed toward osteophyte formation, however, interestingly this was not the case if only $\mathrm{ER} \alpha$ or $\mathrm{ER} \beta$ were genetically deleted (Sniekers et al., 2009). Note that the estrogenrelated receptor is also dysregulated in OA (Bonnelye et al., 2011). The decrease of estrogen levels decrease in older women could therefore contribute to OA, however estrogen replacement provides only modest, and variable improvements to patients (Roman-Blas et al., 2009). Exactly, how estrogen receptors affect joint pathology is not known, but they induce changes in many ECM proteins aggrecan-1, MMP1, MMP2, MMP13, MMP14, and TIMP2 (Claassen et al., 2010; Sniekers et al., 2010) together with some anti-inflammatory action (MartinMillán and Castañeda, 2013). Both the selective estrogen receptor modulator raloxifene and $17 \beta$-estradiol reduce chondrocyte

\section{REFERENCES}

Afif, H., Benderdour, M., Mfuna-Endam, L., Martel-Pelletier, J., Pelletier, J. P., Duval, N., et al. (2007). Peroxisome proliferator-activated receptor gammal expression is diminished in human osteoarthritic cartilage and is downregulated by interleukin-1beta in articular chondrocytes. Arthrit. Res. Therapy 9, R31. doi: 10.1186/ar2151

Akira, S., and Takeda, K. (2004). Toll-like receptor signalling. Nat. Rev. Immunol. 4, 499-511. doi: 10.1038/nri1391

Alexander, S. P., Mathie, A., and Peters, J. A. (2011). Guide to receptors and channels (grac), 5th edition. Br. J. Pharmacol. 164, S1-S324. doi: 10.1111/j. 1476-5381.2011.01649_1.x

Amin, A. R., Attur, M., Patel, R. N., Thakker, G. D., Marshall, P. J., Rediske, J., et al. (1997). Superinduction of cyclooxygenase-2 activity in human osteoarthritisaffected cartilage. Influence of nitric oxide. J. Clin. Invest. 99, 1231-1237. doi: 10.1172/JCI119280

Asahina, Y., Izumi, N., Enomoto, N., Sasaki, S., Fushimi, K., Marumo, F., et al. (1995). Increased gene expression of water channel in cirrhotic rat kidneys. Hepatology 21, 169-173. doi: 10.1002/hep.1840210128

Attur, M., Al-Mussawir, H. E., Patel, J., Kitay, A., Dave, M., Palmer, G., et al. (2008). Prostaglandin E2 exerts catabolic effects in osteoarthritis cartilage: evidence for signaling via the EP4 receptor. J. Immunol. 181, 5082-5088. doi: 10.4049/jimmunol.181.7.5082

Averbeck, B., Rudolphi, K., and Michaelis, M. (2004). Osteoarthritic mice exhibit enhanced prostaglandin e2 and unchanged calcitonin gene-related peptide release in a novel isolated knee joint model. J. Rheumatol. 31, 2013-2020. apoptosis induced by TNF $\alpha$ (Hattori et al., 2012) or doxorubicin. The mechanism of action here has been investigated in some detail with ERK1/2 signaling and inhibition of volume sensitive chloride channels both implicated. The molecular identity of the volume sensitive chloride channel has not yet been confirmed.

\section{CONCLUSION}

Chondrocytes respond to mechanical signals by changing the production of cartilage components. However, the mechanisms of this process are understood only in outline. Membrane receptors and ion channels are well placed to transduce these signals and their differential expression, or post-translational dysfunction could contribute to the progression of OA and other degenerative joint conditions. This review has highlighted a number of such potential biomarkers, the most well established data are summarized in Figure $\mathbf{1}$ and further examples of membrane proteins, with less established but distinct associations with OA are given in Table 1. Many membrane receptors and ion channels altered in either expression and/or function in OA tissue and these may form the basis for biomarker discovery as well as providing deep insight into the mechanisms of cartilage production and provide the basis for development of future biologics for the treatment of degenerative joint conditions.

\section{ACKNOWLEDGMENTS}

The authors wish to acknowledge the D-Board project, which has received funding from the European Union's Seventh Framework Programme for research, technological development and demonstration under grant agreement No. 305815.

Barreto, G., Sillat, T., Soininen, A., Ylinen, P., Salem, A., Konttinen, Y. T., et al. (2013). Do changing toll-like receptor profiles in different layers and grades of osteoarthritis cartilage reflect disease severity? J. Rheumatol. 40, 695-702. doi: 10.3899/jrheum.121159

Bauge, C., Duval, E., Ollitrault, D., Girard, N., Leclercq, S., Galera, P., et al. (2013). Type II TGF beta receptor modulates chondrocyte phenotype. Age 35, 1105-1116. doi: 10.1007/s11357-012-9433-7

Becher, C., Szuwart, T., Ronstedt, P., Ostermeier, S., Skwara, A., FuchsWinkelmann, S., et al. (2010). Decrease in the expression of the type 1 $\mathrm{PTH} / \mathrm{PTHrP}$ receptor (PTH1R) on chondrocytes in animals with osteoarthritis. J. Orthop. Surg. Res. 5:28. doi: 10.1186/1749-799X-5-28

Bonnelye, E., Reboul, P., Duval, N., Cardelli, M., and Aubin, J. E. (2011). Estrogen receptor-related receptor alpha regulation by interleukin-1beta in prostaglandin E(2)- and cAMP-dependent pathways in osteoarthritic chondrocytes. Arthrit. Rheum. 63, 2374-2384. doi: 10.1002/art.30398

Brandt, K. D. (2003). Response of joint structures to inactivity and to reloading after immobilization. Arthrit. Rheum. 49, 267-271. doi: 10.1002/art. 11009

Bush, P. G., Hodkinson, P. D., Hamilton, G. L., and Hall, A. C. (2005). Viability and volume of in situ bovine articular chondrocytes-changes following a single impact and effects of medium osmolarity. Osteoarthritis Cartilage 13, 54-65. doi: 10.1016/j.joca.2004.10.007

Campo, G. M., Avenoso, A., D’Ascola, A., Prestipino, V., Scuruchi, M., Nastasi, G., et al. (2012a). Protein kinase a mediated anti-inflammatory effects exerted by adenosine treatment in mouse chondrocytes stimulated with IL-1beta. Biofactors 38, 429-439. doi: 10.1002/biof.1040 
Campo, G. M., Avenoso, A., D’Ascola, A., Scuruchi, M., Prestipino, V., Nastasi, G., et al. (2012b). Adenosine A2A receptor activation and hyaluronan fragment inhibition reduce inflammation in mouse articular chondrocytes stimulated with interleukin-1beta. Febs J. 279, 2120-2133. doi: 10.1111/j.17424658.2012.08598.x

Cecil, D. L., Appleton, C. T. G., Polewski, M. D., Mort, J. S., Schmidt, A. M., Bendele, A., et al. (2009). The pattern recognition receptor CD36 is a chondrocyte hypertrophy marker associated with suppression of catabolic responses and promotion of repair responses to inflammatory stimuli. J. Immunol. 182, 5024-5031. doi: 10.4049/jimmunol.0803603

Cesare, P., and McNaughton, P. (1996). A novel heat-activated current in nociceptive neurons and its sensitization by bradykinin. Proc. Natl. Acad. Sci. U.S.A. 93, 15435-15439. doi: 10.1073/pnas.93.26.15435

Chen, S., Zhou, Y., Li, J., Shan, L. Q., and Fan, Q. Y. (2012). The effect of bradykinin $\mathrm{B} 2$ receptor polymorphisms on the susceptibility and severity of osteoarthritis in a Chinese cohort. J. Biomed. Biotechnol. 2012:597637. doi: 10.1155/2012/597637

Chen, Y. J., Sheu, M. L., Tsai, K. S., Yang, R. S., and Liu, S. H. (2013). Advanced glycation end products induce peroxisome proliferator-activated receptor gamma down-regulation-related inflammatory signals in human chondrocytes via toll-like receptor- 4 and receptor for advanced glycation end products. PLoS ONE 8:e66611. doi: 10.1371/journal.pone.0066611

Claassen, H., Steffen, R., Hassenpflug, J., Varoga, D., Wruck, C. J., Brandenburg, L. O., et al. (2010). 17 beta-estradiol reduces expression of MMP-1,-3, and 13 in human primary articular chondrocytes from female patients cultured in a three dimensional alginate system. Cell Tissue Res. 342, 283-293. doi: 10.1007/s00441-010-1062-9

Clark, A. L., Votta, B. J., Kumar, S., Liedtke, W., and Guilak, F. (2010). Chondroprotective role of the osmotically-sensitive ion channel TRPV4: Ageand sex-dependent progression of osteoarthritis in Trpv4 deficient mice. Arthritis Rheum. 10, 2973-2983. doi: 10.1002/art.27624

Cotofana, S., Wyman, B. T., Benichou, O., Dreher, D., Nevitt, M., Gardiner, J., et al. (2013). Relationship between knee pain and the presence, location, size and phenotype of femorotibial denuded areas of subchondral bone as visualized by MRI. Osteoarthritis Cartilage 21, 1214-1222. doi: 10.1016/j.joca.2013.04.001

Eckstein, F., Collins, J. E., Nevitt, M. C., Lynch, J. A., Kraus, V., Katz, J. N., et al. (2015). Brief Report: Cartilage thickness change as an imaging biomarker of knee osteoarthritis progression: data from the foundation for the National Institutes of Health Osteoarthritis Biomarkers Consortium. Arthritis Rheumatol. 67, 3184-3189. doi: 10.1002/art.39324

Eisen, V. (1970). Plasma kinins in synovial exudates. Br. J. Exp. Pathol. 51, 322-327.

Ellman, M. B., Yan, D., Ahmadinia, K., Chen, D., An, H. S., and Im, H. J. (2013). Fibroblast growth factor control of cartilage homeostasis. J. Cell. Biochem. 114, 735-742. doi: 10.1002/jcb.24418

Fahmi, H., Martel-Pelletier, J., Pelletier, J. P., and Kapoor, M. (2011). Peroxisome proliferator-activated receptor gamma in osteoarthritis. Modern Rheumatol. 21, 1-9. doi: 10.3109/s10165-010-0347-x

Francin, P. J., Guillaume, C., Humbert, A. C., Pottie, P., Netter, P., Mainard, D., et al. (2011). Association between the chondrocyte phenotype and the expression of adipokines and their receptors: evidence for a role of leptin but not adiponectin in the expression of cartilage-specific markers. J. Cell. Physiol. 226, 2790-2797. doi: 10.1002/jcp.22627

Funabashi, K., Ohya, S., Yamamura, H., Hatano, N., Muraki, K., Giles, W., et al. (2010). Accelerated $\mathrm{Ca} 2+$ entry by membrane hyperpolarization due to $\mathrm{Ca} 2+-$ activated $\mathrm{K}+$ channel activation in response to histamine in chondrocytes. Am. J. Physiol. Cell Physiol. 298, C786-C797. doi: 10.1152/ajpcell.00469.2009

Gao, X., Cui, Y., Levenson, R. M., Chung, L. W., and Nie, S. (2004). In vivo cancer targeting and imaging with semiconductor quantum dots. Nat. Biotechnol. 22, 969-976. doi: 10.1038/nbt994

Garcia, M., and Knight, M. M. (2010). Cyclic loading opens hemichannels to release ATP as part of a chondrocyte mechanotransduction pathway. J. Orthop. Res. 28, 510-515. doi: 10.1002/jor.21025

Geyer, M., Grässel, S., Straub, R. H., Schett, G., Dinser, R., Grifka, J., et al. (2009). Differential transcriptome analysis of intraarticular lesional vs intact cartilage reveals new candidate genes in osteoarthritis pathophysiology. Osteoarthritis Cartilage 17, 328-335. doi: 10.1016/j.joca.2008.07.010

Grässel, S., Opolka, A., Anders, S., Straub, R. H., Grifka, J., Luger, T. A., et al. (2009). The melanocortin system in articular chondrocytes melanocortin receptors, pro-opiomelanocortin, precursor proteases, and a regulatory effect of alpha-melanocyte-stimulating hormone on proinflammatory cytokines and extracellular matrix components. Arthritis Rheum. 60, 3017-3027. doi: 10.1002/art.24846

Guilak, F. (2011). Biomechanical factors in osteoarthritis. Best Practice Res. Clin. Rheumatol. 25, 815-823. doi: 10.1016/j.berh.2011.11.013

Guilak, F., Leddy, H. A., and Liedtke, W. (2010). Transient receptor potential vanilloid 4: the sixth sense of the musculoskeletal system? Ann. N.Y. Acad. Sci. U.S.A. 1192, 404-409. doi: 10.1111/j.1749-6632.2010.05389.x

Hagiwara, K., Shinozaki, T., Matsuzaki, T., Takata, K., and Takagishi, K. (2013). Immunolocalization of water channel aquaporins in human knee articular cartilage with intact and early degenerative regions. Med. Mol. Morphol. 46 104-108. doi: 10.1007/s00795-013-0014-3

Hattori, Y., Kojima, T., Kato, D., Matsubara, H., Takigawa, M., and Ishiguro, N. (2012). A selective estrogen receptor modulator inhibits tumor necrosis factor-alpha-induced apoptosis through the ERK1/2 signaling pathway in human chondrocytes. Biochem. Biophys. Res. Commun. 421, 418-424. doi: 10.1016/j.bbrc.2012.03.111

Hdud, I. M., El-Shafei, A. A., Loughna, P., Barrett-Jolley, R., and Mobasheri, A. (2012). Expression of Transient Receptor Potential Vanilloid (TRPV) channels in different passages of articular chondrocytes. Int. J. Mol. Sci. 13, 4433-4445. doi: 10.3390/Ijms13044433

Hoffmann, E. K., Lambert, I. H., and Pedersen, S. F. (2009). Physiology of cell volume regulation in vertebrates. Physiol. Rev. 89, 193-277. doi: 10.1152/physrev.00037.2007

Huang, J., Zhang, X., and McNaughton, P. A. (2006). Inflammatory pain: the cellular basis of heat hyperalgesia. Curr. Neuropharmacol. 4, 197-206. doi: $10.2174 / 157015906778019554$

Hunter, D. J., Guermazi, A., Roemer, F., Zhang, Y., and Neogi, T. (2013). Structural correlates of pain in joints with osteoarthritis. Osteoarthritis Cartilage 21, 1170-1178. doi: 10.1016/j.joca.2013.05.017

Hwang, D. W., Ko, H. Y., Lee, J. H., Kang, H., Ryu, S. H., Song, I. C., et al. (2010). A nucleolin-targeted multimodal nanoparticle imaging probe for tracking cancer cells using an aptamer. J. Nuclear Med. 51, 98-105. doi: 10.2967/jnumed.109.069880

Iliopoulos, D., Malizos, K. N., and Tsezou, A. (2007). Epigenetic regulation of leptin affects MMP-13 expression in osteoarthritic chondrocytes: possible molecular target for osteoarthritis therapeutic intervention. Ann. Rheum. Dis. 66, 1616-1621. doi: 10.1136/ard.2007.069377

Inayama, M., Suzuki, Y., Yamada, S., Kurita, T., Yamamura, H., Ohya, S., et al. (2015). Orai1-Orai2 complex is involved in store-operated calcium entry in chondrocyte cell lines. Cell Calcium 57, 337-347. doi: 10.1016/j.ceca.2015.02.005

Ivarsen, P., Frøkiaer, J., Aagaard, N. K., Hansen, E. F., Bendtsen, F., Nielsen, S., et al. (2003). Increased urinary excretion of aquaporin 2 in patients with liver cirrhosis. Gut 52, 1194-1199. doi: 10.1136/gut.52.8.1194

Jean, Y. H., Wen, Z. H., Chang, Y. C., Hsieh, S. P., Tang, C. C., Wang, Y. H., et al. (2007). Intra-articular injection of the cyclooxygenase-2 inhibitor parecoxib attenuates osteoarthritis progression in anterior cruciate ligament-transected knee in rats: role of excitatory amino acids. Osteoarthr. Cartil. 15, 638-645. doi: 10.1016/j.joca.2006.11.008

Jean, Y. H., Wen, Z. H., Chang, Y. C., Huang, G. S., Lee, H. S., Hsieh, S. P. et al. (2005). Increased concentrations of neuro-excitatory amino acids in rat anterior cruciate ligament-transected knee joint dialysates: a microdialysis study. J. Orthop. Res. 23, 569-575. doi: 10.1016/j.orthres.2004.12.015

Jean, Y. H., Wen, Z. H., Chang, Y. C., Lee, H. S., Hsieh, S. P., Wu, C. T., et al. (2006). Hyaluronic acid attenuates osteoarthritis development in the anterior cruciate ligament-transected knee: association with excitatory amino acid release in the joint dialysate. J. Orthop. Res. 24, 1052-1061. doi: 10.1002/jor. 20123

Johnson, C. I., Argyle, D. J., and Clements, D. N. (in press). In vitro models for the study of osteoarthritis. Veterinary J. doi: 10.1016/j.tvjl.2015.07.011

Julovi, S. M., Ito, H., Nishitani, K., Jackson, C. J., and Nakamura, T. (2011). Hyaluronan inhibits matrix metalloproteinase-13 in human arthritic chondrocytes via CD44 and P38. J. Orthop. Res. 29, 258-264. doi: 10.1002/jor.21216

Kaneva, M. K., Kerrigan, M. J. P., Grieco, P., Curley, G. P., Locke, I. C. and Getting, S. J. (2012). Chondroprotective and anti-inflammatory role of 
melanocortin peptides in TNF-alpha activated human C-20/A4 chondrocytes. Br. J. Pharmacol. 167, 67-79. doi: 10.1111/j.1476-5381.2012.01968.x

Karlsson, C., Dehne, T., Lindahl, A., Brittberg, M., Pruss, A., Sittinger, M., et al. (2010). Genome-wide expression profiling reveals new candidate genes associated with osteoarthritis. Osteoarthritis Cartilage 18, 581-592. doi: 10.1016/j.joca.2009.12.002

Kerkhof, H. J. M., Meulenbelt, I., Carr, A., Gonzalez, A., Hart, D., Hofman, A., et al. (2010). Common genetic variation in the Estrogen Receptor Beta (ESR2) gene and osteoarthritis: results of a meta-analysis. BMC Med. Genet. 11:164. doi: 10.1186/1471-2350-11-164

Knight, M. M., McGlashan, S. R., Garcia, M., Jensen, C. G., and Poole, C. A. (2009). Articular chondrocytes express connexin 43 hemichannels and P2 receptors - a putative mechanoreceptor complex involving the primary cilium? J. Anat. 214, 275-283. doi: 10.1111/j.1469-7580.2008.01021.x

Koskinen, A., Vuolteenaho, K., Nieminen, R., Moilanen, T., and Moilanen, E. (2011). Leptin enhances MMP-1, MMP-3 and MMP-13 production in human osteoarthritic cartilage and correlates with MMP- 1 and MMP-3 in synovial fluid from OA patients. Clin. Exp. Rheumatol. 29, 57-64.

Kurita, T., Yamamura, H., Suzuki, Y., Giles, W. R., and Imaizumi, Y. (2015). The ClC-7 chloride channel is downregulated by hypoosmotic stress in human chondrocytes. Mol. Pharmacol. 88, 113-120. doi: 10.1124/mol.115. 098160

Kuroki, K., Stoker, A. M., Sims, H. J., and Cook, J. L. (2010). Expression of Tolllike receptors 2 and 4 in stifle joint synovial tissues of dogs with or without osteoarthritis. Am. J. Vet. Res. 71, 750-754. doi: 10.2460/ajvr.71.7.750

Lamandé, S. R., Yuan, Y., Gresshoff, I. L., Rowley, L., Belluoccio, D., Kaluarachchi, K., et al. (2011). Mutations in TRPV4 cause an inherited arthropathy of hands and feet. Nat. Genet. 43, 1142-1146. doi: 10.1038/ng.945

Lee, C. H., Wen, Z. H., Chang, Y. C., Huang, S. Y., Tang, C. C., Chen, W. F., et al. (2009). Intra-articular magnesium sulfate (MgSO4) reduces experimental osteoarthritis and nociception: association with attenuation of N-methyl-D-aspartate (NMDA) receptor subunit 1 phosphorylation and apoptosis in rat chondrocytes. Osteoarthritis Cartilage 17, 1485-1493. doi: 10.1016/j.joca.2009.05.006

Lee, W., Leddy, H. A., Chen, Y., Lee, S. H., Zelenski, N. A., McNulty, A. L., et al. (2014). Synergy between Piezol and Piezo2 channels confers high-strain mechanosensitivity to articular cartilage. Proc. Natl. Acad. Sci. 111, E5114E5122. doi: 10.1073/pnas.1414298111

Lewis, R., Asplin, K. E., Bruce, G., Dart, C., Mobasheri, A., and Barrett-Jolley, R. (2011a). The role of the membrane potential in chondrocyte volume regulation. J. Cell. Physiol. 226, 2979-2986. doi: 10.1002/jcp.22646

Lewis, R., Feetham, C., and Barrett-Jolley, R. (2011b). Cell volume control in chondrocytes. Cell. Physiol. Biochem. 28, 1111-1122. doi: 10.1159/000335847

Lewis, R., Feetham, C. H., Gentles, L., Penny, J., Tregilgas, L., Tohami, W., et al. (2013a). Benzamil sensitive ion channels contribute to volume regulation in canine chondrocytes. Br. J. Pharmacol. 168, 1584-1596. doi: 10.1111/j.14765381.2012.02185.x

Lewis, R., May, H., Mobasheri, A., and Barrett-Jolley, R. (2013b). Chondrocyte channel transcriptomics: do microarray data fit with expression and functional data? Channels 7, 459-467. doi: 10.4161/chan.26071

Li, X., Ellman, M., Muddasani, P., Wang, J. H., Cs-Szabo, G., van Wijnen, A. J., et al. (2009). Prostaglandin E2 and its cognate EP receptors control human adult articular cartilage homeostasis and are linked to the pathophysiology of osteoarthritis. Arthritis Rheum. 60, 513-523. doi: 10.1002/art.24258

Martel-Pelletier, J., Pelletier, J.-P., and Fahmi, H. (2003). Cyclooxygenase-2 and prostaglandins in articular tissues. Semin. Arthritis Rheum. 33, 155-167. doi: 10.1016/S0049-0172(03)00134-3

Martin-Millán, M., and Castañeda, S. (2013). Estrogens, osteoarthritis and inflammation. Joint Bone Spine 80, 368-373. doi: 10.1016/j.jbspin.2012.11.008

May, P., Woldt, E., Matz, R. L., and Boucher, P. (2007). The LDL receptorrelated protein (LRP) family: an old family of proteins with new physiological functions. Ann. Med. 39, 219-228. doi: 10.1080/07853890701214881

Meini, S., Cucchi, P., Catalani, C., Bellucci, F., Giuliani, S., and Maggi, C. A. (2011). Bradykinin and $\mathrm{B}(2)$ receptor antagonism in rat and human articular chondrocytes. Br. J. Pharmacol. 162, 611-622. doi: 10.1111/j.14765381.2010.01062.x

Meini, S., and Maggi, C. A. (2008). Knee osteoarthritis: a role for bradykinin? Inflammat. Res. 57, 351-361. doi: 10.1007/s00011-007-7204-1
Melmon, K. L., Webster, M. E., Goldfinger, S. E., and Seegmiller, J. E. (1967). The presence of a kinin in inflammatory synovial effusion from arthritides of varying etiologies. Arthritis Rheum. 10, 13-20. doi: 10.1002/art.1780100103

Milentijevic, D., Helfet, D. L., and Torzilli, P. A. (2003). Influence of stress magnitude on water loss and chondrocyte viability in impacted articular cartilage. J. Biomech. Eng. Trans. Asme 125, 594-601. doi: 10.1115/ 1.1610021

Millward-Sadler, S. J., Wright, M. O., Davies, L. W., Nuki, G., and Salter, D. M. (2000). Mechanotransduction via integrins and interleukin-4 results in altered aggrecan and matrix metalloproteinase 3 gene expression in normal, but not osteoarthritic, human articular chondrocytes. Arthritis Rheum. 43, 2091-2099. doi: 10.1002/1529-0131(200009)43:9<2091::AID-ANR21>3.0.CO;2-C

Millward-Sadler, S. J., Wright, M. O., Flatman, P. W., and Salter, D. M. (2004). ATP in the mechanotransduction pathway of normal human chondrocytes. Biorheology 41, 567-575.

Mitsui, H., Aoyama, T., Furu, M., Ito, K., Jin, Y., Maruyama, T., et al. (2011). Prostaglandin E2 receptor type 2-selective agonist prevents the degeneration of articular cartilage in rabbit knees with traumatic instability. Arthritis Res. Therapy 13, R146. doi: 10.1186/ar3460

Mobasheri, A., Carter, S. D., Martín-Vasallo, P., and Shakibaei, M. (2002). Integrins and stretch activated ion channels; putative components of functional cell surface mechanoreceptors in articular chondrocytes. Cell Biol. Int. 26, 1-18. doi: 10.1006/cbir.2001.0826

Mobasheri, A., Gent, T. C., Nash, A. I., Womack, M. D., Moskaluk, C. A., and Barrett-Jolley, R. (2007). Evidence for functional ATP-sensitive (k-ATP) potassium channels in human and equine articular chondrocytes. Osteoarthritis Cartilage 15, 1-8. doi: 10.1016/j.joca.2006.06.017

Musumeci, G., Leonardi, R., Carnazza, M. L., Cardile, V., Pichler, K., Weinberg, A. M., et al. (2013). Aquaporin 1 (AQP1) expression in experimentally induced osteoarthritic knee menisci: an in vivo and in vitro study. Tissue Cell 45, 145-152. doi: 10.1016/j.tice.2012.10.004

Natoli, R. M., Scott, C. C., and Athanasiou, K. A. (2008). Temporal effects of impact on articular cartilage cell death, gene expression, matrix biochemistry, and biomechanics. Ann. Biomed. Eng. 36, 780-792. doi: 10.1007/s10439-008-9472-5

Nebbaki, S. S., El Mansouri, F. E., Afif, H., Kapoor, M., Benderdour, M., Duval, N., et al. (2012). Egr-1 contributes to IL-1-mediated downregulation of peroxisome proliferator-activated receptor gamma expression in human osteoarthritic chondrocytes. Arthritis Res. Ther. 14:R69. doi: 10.1186/ar3788

Nebbaki, S. S., El Mansouri, F. E., Afif, H., Kapoor, M., Benderdour, M., Pelletier, J. P., et al. (2013). Expression of peroxisome proliferator-activated receptors alpha, beta, gamma, and $\mathrm{H}$ - and L-Prostaglandin D synthase during osteoarthritis in the spontaneous hartley guinea pig and experimental dog models. J. Rheumatol. 40, 877-890. doi: 10.3899/jrheum.120738

O'Conor, C. J., Griffin, T. M., Liedtke, W., and Guilak, F. (2013). Increased susceptibility of Trpv4-deficient mice to obesity and obesity-induced osteoarthritis with very high-fat diet. Ann. Rheum. Dis. 72, 300-304. doi: 10.1136/annrheumdis-2012-202272

Otsuka, S., Aoyama, T., Furu, M., Ito, K., Jin, Y., Nasu, A., et al. (2009). PGE2 signal via EP2 receptors evoked by a selective agonist enhances regeneration of injured articular cartilage. Osteoarthritis Cartilage 17, 529-538. doi: 10.1016/j.joca.2008.09.003

Pap, T., and Bertrand, J. (2013). Syndecans in cartilage breakdown and synovial inflammation. Nat. Rev. Rheumatol. 9, 43-55. doi: 10.1038/nrrheum. 2012.178

Pawson, A. J., Sharman, J. L., Benson, H. E., Faccenda, E., Alexander, S. P., Buneman, O. P., et al. (2014). The IUPHAR/BPS Guide to PHARMACOLOGY: an expert-driven knowledgebase of drug targets and their ligands. Nucleic Acids Res. 42, D1098-D1106. doi: 10.1093/nar/gkt1143

Pedersen, R. S., Bentzen, H., Bech, J. N., Nyvad, O., and Pedersen, E. B. (2003). Urinary aquaporin-2 in healthy humans and patients with liver cirrhosis and chronic heart failure during baseline conditions and after acute water load. Kidney Int. 63, 1417-1425. doi: 10.1046/j.1523-1755.2003.00858.x

Pfander, D., Cramer, T., Deuerling, D., Weseloh, G., and Swoboda, B. (2000). Expression of thrombospondin-1 and its receptor CD36 in human osteoarthritic cartilage. Ann. Rheum. Dis. 59, 448-454. doi: 10.1136/ard.59.6.448

Piepoli, T., Mennuni, L., Zerbi, S., Lanza, M., Rovati, L. C., and Caselli, G. (2009). Glutamate signaling in chondrocytes and the potential involvement of NMDA 
receptors in cell proliferation and inflammatory gene expression. Osteoarthritis Cartilage 17, 1076-1083. doi: 10.1016/j.joca.2009.02.002

Pingguan-Murphy, B., El-Azzeh, M., Bader, D. L., and Knight, M. M. (2006). Cyclic compression of chondrocytes modulates a purinergic calcium signalling pathway in a strain rate- and frequency-dependent manner. J. Cell. Physiol. 209, 389-397. doi: 10.1002/jcp.20747

Quinn, T. M., Allen, R. G., Schalet, B. J., Perumbuli, P., and Hunziker, E. B. (2001). Matrix and cell injury due to sub-impact loading of adult bovine articular cartilage explants: effects of strain rate and peak stress. J. Orthop. Res. 19, 242-249. doi: 10.1016/S0736-0266(00)00025-5

Ramage, L., Martel, M. A., Hardingham, G. E., and Salter, D. M. (2008). NMDA receptor expression and activity in osteoarthritic human articular chondrocytes. Osteoarthritis Cartilage 16, 1576-1584. doi: 10.1016/j.joca.2008.04.023

Renard, E., Porée, B., Chadjichristos, C., Kypriotou, M., Maneix, L., Bigot, N., et al. (2012). Sox9/Sox6 and Sp1 are involved in the insulin-like growth factor-Imediated upregulation of human type II collagen gene expression in articular chondrocytes. J. Mol. Med. (Berl.) 90, 649-666. doi: 10.1007/s00109-011-0842-3

Riancho, J. A., García-Ibarbia, C., Gravani, A., Raine, E. V. A., RodríguezFontenla, C., Soto-Hermida, A., et al. (2010). Common variations in estrogenrelated genes are associated with severe large-joint osteoarthritis: a multicenter genetic and functional study. Osteoarthritis Cartilage 18, 927-933. doi: 10.1016/j.joca.2010.04.002

Roman-Blas, J. A., Castañeda, S., Largo, R., and Herrero-Beaumont, G. (2009). Osteoarthritis associated with estrogen deficiency. Arthritis Res. Ther. 11:241. doi: 10.1186/ar2791

Rosa, S. C., Rufino, A. T., Judas, F., Tenreiro, C., Lopes, M. C., and Mendes, A. F. (2011). Expression and function of the insulin receptor in normal and osteoarthritic human chondrocytes: modulation of anabolic gene expression, glucose transport and GLUT-1 content by insulin. Osteoarthritis Cartilage 19, 719-727. doi: 10.1016/j.joca.2011.02.004

Rosenthal, A. K., Hempel, D., Kurup, I. V., Masuda, I., and Ryan, L. M. (2010). Purine receptors modulate chondrocyte extracellular inorganic pyrophosphate production. Osteoarthritis Cartilage 18, 1496-1501. doi: 10.1016/j.joca.2010.08.004

Rufino, A. T., Rosa, S. C., Judas, F., Mobasheri, A., Lopes, M. C., and Mendes, A. F. (2013). Expression and function of K(ATP) channels in normal and osteoarthritic human chondrocytes: possible role in glucose sensing. J. Cell. Biochem. 114, 1879-1889. doi: 10.1002/jcb.24532

Rushton, M. D., Reynard, L. N., Barter, M. J., Refaie, R., Rankin, K. S., Young, D. A., et al. (2014). Characterization of the cartilage DNA Methylome in knee and hip osteoarthritis. Arthritis Rheumatol. 66, 2450-2460. doi: 10.1002/art. 38713

Schelbergen, R. F. P., Blom, A. B., van den Bosch, M. H. J., Slöetjes, A., AbdollahiRoodsaz, S., Schreurs, B. W., et al. (2012). Alarmins S100A8 and S100A9 elicit a catabolic effect in human osteoarthritic chondrocytes that is dependent on toll-like receptor 4. Arthritis Rheum. 64, 1477-1487. doi: 10.1002/art.33495

Shen, P. C., Shiau, A. L., Jou, I. M., Lee, C. H., Tai, M. H., Juan, H. Y., et al. (2011). Inhibition of cartilage damage by pro-opiomelanocortin prohormone overexpression in a rat model of osteoarthritis. Exp. Biol. Med. 236, 334-340. doi: 10.1258/ebm.2010.010319

Silverstein, R. L., and Febbraio, M. (2009). CD36, a scavenger receptor involved in immunity, metabolism, angiogenesis, and behavior. Sci. Signal. 2:re3. doi: 10.1126/scisignal.272re3

Sniekers, Y. H., van Osch, G., Ederveen, A. G. H., Inzunza, J., Gustafsson, J. A., van Leeuwen, J. P., et al. (2009). Development of osteoarthritic features in estrogen receptor knockout mice. Osteoarthritis Cartilage 17, 1356-1361. doi: 10.1016/j.joca.2009.04.008

Sniekers, Y. H., van Osch, G., Jahr, H., Weinans, H., and van Leeuwen, J. P. (2010). Estrogen modulates iodoacetate-induced gene expression in bovine cartilage explants. J. Orthop. Res. 28, 607-615. doi: 10.1002/jor.21042

Strimbu, K., and Tavel, J. A. (2010). What are Biomarkers? Curr. Opin. HIV AIDS 5, 463-466. doi: 10.1097/COH.0b013e32833ed177
Su, S. L., Yang, H. Y., Lee, C. H., Huang, G. S., Salter, D. M., and Lee, H. S. (2012) The $(-1486 \mathrm{~T} / \mathrm{C})$ promoter polymorphism of the TLR-9 gene is associated with end-stage knee osteoarthritis in a Chinese population. J. Orthop. Res. 30, 9-14. doi: 10.1002/jor.21494

Tetlow, L. C., and Woolley, D. E. (2005). Histamine, histamine receptors (H1 and $\mathrm{H} 2$ ), and histidine decarboxylase expression by chondrocytes of osteoarthritic cartilage: an immunohistochemical study. Rheumatol. Int. 26, 173-178. doi: 10.1007/s00296-005-0622-x

Thakur, M., Dawes, J. M., and McMahon, S. B. (2013). Genomics of pain in osteoarthritis. Osteoarthritis Cartilage 21, 1374-1382. doi: 10.1016/j.joca.2013. 06.010

Urban, J. P. (1994). The chondrocyte: a cell under pressure. Br. J. Rheumatol. 33, 901-908. doi: 10.1093/rheumatology/33.10.901

Ushiyama, T., Ueyama, H., Inoue, K., Ohkubo, I., and Hukuda, S. (1999). Expression of genes for estrogen receptors alpha and beta in human articular chondrocytes. Osteoarthritis Cartilage 7, 560-566. doi: 10.1053/joca.1999.0260

Varani, K., De Mattei, M., Vincenzi, F., Tosi, A., Gessi, S., Merighi, S., et al. (2008). Pharmacological characterization of P2X1 and P2X3 purinergic receptors in bovine chondrocytes. Osteoarthritis Cartilage 16, 1421-1429. doi: 10.1016/j.joca.2008.03.016

Vincent, T. L. (2012). Explaining the fibroblast growth factor paradox in osteoarthritis: lessons from conditional knockout mice. Arthritis Rheum. 64, 3835-3838. doi: 10.1002/art.34648

Vincent, T. L. (2013). Targeting mechanotransduction pathways in osteoarthritis: a focus on the pericellular matrix. Curr. Opin. Pharmacol. 13, 449-454. doi: 10.1016/j.coph.2013.01.010

Vincent, T. L., McLean, C. J., Full, L. E., Peston, D., and Saklatvala, J. (2007). FGF2 is bound to perlecan in the pericellular matrix of articular cartilage, where it acts as a chondrocyte mechanotransducer. Osteoarthritis Cartilage 15, 752-763. doi: 10.1016/j.joca.2007.01.021

Xu, J., Wang, W., Clark, C. C., and Brighton, C. T. (2009). Signal transduction in electrically stimulated articular chondrocytes involves translocation of extracellular calcium through voltage-gated channels. Osteoarthritis Cartilage 17, 397-405. doi: 10.1016/j.joca.2008.07.001

Yamaura, K., Akiyama, S., and Ueno, K. (2012a). Increased expression of the histamine $\mathrm{H} 4$ receptor subtype in hypertrophic differentiation of chondrogenic ATDC5 cells. J. Cell. Biochem. 113, 1054-1060. doi: 10.1002/jcb.23436

Yamaura, K., Oda, M., Suzuki, M., and Ueno, K. (2012b). Lower expression of histamine $\mathrm{H}(4)$ receptor in synovial tissues from patients with rheumatoid arthritis compared to those with osteoarthritis. Rheumatol. Int. 32, 3309-3313. doi: 10.1007/s00296-011-2069-6

Yang, H. Y., Lee, H. S., Lee, C. H., Fang, W. H., Chen, H. C., Salter, D. M., et al. (2013). Association of a functional polymorphism in the promoter region of TLR-3 with osteoarthritis: a two-stage casecontrol study. J. Orthop. Res. 31, 680-685. doi: 10.1002/jor.22291

Yatabe, T., Mochizuki, S., Takizawa, M., Chijiiwa, M., Okada, A., Kimura, T., et al. (2009). Hyaluronan inhibits expression of ADAMTS4 (aggrecanase-1) in human osteoarthritic chondrocytes. Ann. Rheum. Dis. 68, 1051-1058. doi: 10.1136/ard.2007.086884

Zhen, G., Wen, C., Jia, X., Li, Y., Crane, J. L., Mears, S. C., et al. (2013). Inhibition of TGF-beta signaling in mesenchymal stem cells of subchondral bone attenuates osteoarthritis. Nat. Med. 19, 704-712. doi: 10.1038/nm.3143

Conflict of Interest Statement: The authors declare that the research was conducted in the absence of any commercial or financial relationships that could be construed as a potential conflict of interest.

Copyright (c) 2015 Lewis and Barrett-Jolley. This is an open-access article distributed under the terms of the Creative Commons Attribution License (CC BY). The use, distribution or reproduction in other forums is permitted, provided the original author(s) or licensor are credited and that the original publication in this journal is cited, in accordance with accepted academic practice. No use, distribution or reproduction is permitted which does not comply with these terms. 